Abstract. The article presents the results of studies on the effectiveness of processing of winter wheat crops with modern growth-regulating drugs on the background of mineral fertilizers, carried out in 2011-2016 on the southern bleak soils in the southern Steppe of Ukraine. It was studied the influence of varietal characteristics of winter wheat and nutrition variants on the formation of yield structure and grain yield. It was determined the fertilization in the presowing cultivation of two winter wheat varieties at a dose of $N_{30} P_{30}$ (background) and the use of foliar dressing crops at the beginning of the resumption of spring vegetation and the beginning of the plant stooling by preparations Organic D2 and Escort-bio created favorable conditions for the formation of the best indicators of the yield structure, and hence the highest level of grain yield of the studied varieties. For example, in average for years of cultivation, in given nutrition variants the grain yield of the Kolchuga variety was formed at a rate of 4,42-4,48 $t /$ ha and the grain yield of the Zamozhnist variety at a rate of 4,96-4,99 $\mathrm{t} / \mathrm{h}$. These indicators exceeded the control by 52.9-55,0\% and 62.6-63.6\% respectively.

The superior of the studied winter wheat varieties by a set of indicators was the Zamozhnist variety.

Keywords: wheat, variety, plant nutrition, growth-regulating drugs, the yield structure, grain yield

UDC 631.452: 631.6.02: 631.584.4: 631.445.4 (477)

\title{
AGGREGATE STABILITY AND SIZE DISTRIBUTION IN UKRAINIAN AND CHINESE MOLLISOLS UNDER DIFFERENT TILLAGE
}

\author{
Y. S.KRAVCHENKO, PhD, Associate Professor, \\ Soil Science and Soil Conservation Department, NUBiP of Ukraine \\ E-mail:kravch@i.ua
}

\begin{abstract}
A study was attempted to interpret the effects of land use on soil aggregates distribution on Ukrainian and Chinese Mollisols. A great attention was devoted to the studying conservational tillage. These researches were fulfilled on experimental stations located in the Forest-Steppe zone of Ukraine (Velykosnyatynsky town, Kyiv region) and in the Heilongjiang Province of China (Hailun city, North-East China). The results have showed that no-till and minimum tillage increased amount of agronomical valuable $10-0.25 \mathrm{~mm}$ air-dry aggregates, favored generating of water stable aggregates above 0.5 $\mathrm{mm}$ in diameter, formed higher values of the mean weight (MWD) and the geometric mean (GMD) diameters and lower fractal dimensions ((3-y/x (Df)).

Keywords: Mollisols, aggregates, conservation tillage, geometric mean diameter
\end{abstract}


Introduction. Soil structure has a profound impact on plant growth conditions, sustains soil fertility, protects soil organic matter from mineralization, mediates soil aeration and water infiltration as well as may reduce soil erosion. Both dynamics and size distribution of soil aggregates effect on soil processes and agricultural practices applied (Zhao et al., 2017). Such land use as: tillage, crop rotation, fertilization, water and chemical melioration are direct ways to affect soil structure and corresponding soil properties. Different tillage practices vary in their effect the soil aggregate size distribution. Admittedly, that the conventional system of soil tillage destroys soil structure, accelerates the decomposition of soil organic matter and nutrient loss, which leads farmland to unstable and declining in crop yields (Hou et al., 2013). Meanwhile, the long-term minimum tillage causes considerable improvement in soil properties, SOM and SOC content, cation exchange capacity and decrease the $\mathrm{C} / \mathrm{N}$ ratio (Irfan et al., 2013). No- tillage stores of diverse plant biomass on undisturbed surface, but may extent of subsurface compaction and bulk density problem as well as the accumulation of soil organic carbon in surface soil, and a rapid loss of nitrogen (Blanco-Canqui and Lal, 2007).

The effect of tillage practices on soil aggregate size distribution and water stable aggregates (WSA) content is complex and often variable. An accumulation of soil organic matter under minimum and no-tillage compared to conventional tillage confers important improvements in increases of carbonrich macro-aggregates and their reduced rates of turnover (Andruschkewitsch et al., 2014). Six et al., 2000 suggested that slower macro-aggregate turnover may promote the formation of stable micro-aggregates within macroaggregates, which in turn leads to a long-term SOC stabilization. These microaggregates associated with occluded SOC within macro-aggregates may serve as an indicator for management-induced changes in macro-aggregate turnover and C stabilization (Denef et al., 2004; Kong et al., 2005). In this regard, aggregate stability, in this article, is discussed in terms of tillage influence over long period of time. Wet and dry aggregate size distribution, MWD, GMD, the 3-y/x (Df) were determined to define the aggregate stability.

Purpose. The general aim of this paper is to define and summarize the effects of different tillage practices on soil aggregates changes in Ukrainian and Chinese Mollisols.

Materials and Methods: field stationary experiments, laboratory analysis with standard methods, mathematic-statistical calculations.

Ukrainian Typical Mollisol (Typical Chernozem) was studied at the university experiment site, run by Soil Science and Soil Conservation Department (NUBiP of Ukraine), located near the town Velykosnyatynka, in the Kyiv region (lat. $50^{\circ} 5^{\prime} \mathrm{N}$, long. $30^{\circ} 2^{\prime} \mathrm{E}$ ). The average annual temperature is $7.9^{\circ} \mathrm{C}$, annual precipitation about $588 \mathrm{~mm}$. Tillage treatments included conventional tillage (CT) based on deep plowing $(25-30 \mathrm{~cm})$, and two soil conservation tillage based on the deep minimum tillage (DT) to a depth of 25$30 \mathrm{~cm}$, reduced minimum tillage (RT) to a depth of $10-12 \mathrm{~cm}$. The fertilizers supplied at rates $\mathrm{N}_{50} \mathrm{P}_{45} \mathrm{~K}_{45}$ ha $^{-1}$ coupled with annual application of cattle manure at a rate of $12 \mathrm{t} \mathrm{ha}^{-1}$. Crop rotation was made up of five fields. 
The study of Chinese Mollisol (Isohumusol) were fulfilled near Guangrong village $\left(47^{\circ} 23^{\prime} \mathrm{N}, 126^{\circ} 51^{\prime} \mathrm{E}\right), 14.4 \mathrm{~km}$ southwest from Hailun city Heilongjiang province, run by Hailun Monitoring and Research Station of Soil and Water Conservation, Northeast Institute of Geography and Agroecology, Chinese Academy of Sciences. Average annual precipitation is $530 \mathrm{~mm}$, annual average temperature is $1.5^{\circ} \mathrm{C}$. The soil is a typical Mollisols (Udolls), the treatments included three tillage systems and abandoned plot (Ab): no-till (NT), reduced-till (RT) and convention tillage (CT). Fertilizer was applied at $138 \mathrm{~kg} \mathrm{~N} \mathrm{ha}^{-1}, 51.75 \mathrm{~kg} \mathrm{P} \mathrm{ha}^{-1}$, and $15 \mathrm{~kg} \mathrm{~K} \mathrm{ha}^{-1}$. Major properties of Ukrainian and Chinese Mollisols are presented in the table 1.

\section{Major properties of the studied Ukrainian and Chinese Mollisols}

\begin{tabular}{|c|c|c|c|c|c|c|c|c|c|}
\hline \multirow{2}{*}{$\begin{array}{l}\text { Soil } \\
\text { depth, } \\
\mathrm{cm}\end{array}$} & \multirow{2}{*}{$\begin{array}{c}\text { Hu- } \\
\text { mus } \\
\text { con- } \\
\text { tent, } \\
\%\end{array}$} & \multirow{2}{*}{$\begin{array}{c}\mathrm{pH}_{\mathrm{H}_{2}} \\
\mathrm{O}\end{array}$} & \multirow{2}{*}{$\begin{array}{c}\text { Bulk } \\
\text { density, } \\
\mathrm{g} \mathrm{cm}^{-3}\end{array}$} & \multirow{2}{*}{$\begin{array}{l}\text { Full } \\
\text { capaci } \\
\text { ty, \% }\end{array}$} & \multirow{2}{*}{$\begin{array}{c}\text { PWP, } \\
\%\end{array}$} & \multicolumn{4}{|c|}{$\begin{array}{l}\text { Particles fractions }(\mathrm{mm}) \text { and } \\
\text { their content, } \%\end{array}$} \\
\hline & & & & & & \multicolumn{2}{|c|}{ sand } & silt & clay \\
\hline & & Typ & al Velyko & רyatynk & $\mathrm{s}$ cherno & $\begin{array}{c}\text { em, U } \\
(1- \\
0,25)\end{array}$ & $\begin{array}{c}\text { raine } \\
(0,25- \\
0,05)\end{array}$ & $\begin{array}{l}(0,05- \\
0,001)\end{array}$ & $\begin{array}{l}(<0,00 \\
1)\end{array}$ \\
\hline $0-25$ & 3,6 & 6,7 & 1,29 & 45,5 & 10,40 & 0,48 & 10,9 & 57,2 & 31,42 \\
\hline $25-45$ & 3,4 & 6,7 & 1,33 & 22,3 & 10,28 & - & & - & \\
\hline $45-65$ & 3,1 & 6,9 & & 23,9 & 10,28 & - & - & - & - \\
\hline & & & & Molliso & China & $\begin{array}{c}(2- \\
0,25)\end{array}$ & $\begin{array}{c}(0,25- \\
0,02)\end{array}$ & $\begin{array}{l}(0,02- \\
0,002)\end{array}$ & $\begin{array}{l}(<0,00 \\
1)\end{array}$ \\
\hline $0-20$ & 4,5 & 6,6 & 1,27 & 48,3 & 17,0 & 1,15 & 35,99 & 25,83 & 37,03 \\
\hline $20-50$ & 4,4 & 6,7 & 1,19 & 44,2 & 17,1 & 1,73 & 25,77 & 26,47 & 46,03 \\
\hline $50-70$ & 3,4 & 6,6 & 1,21 & 43,6 & 16,9 & 1,40 & 27,85 & 26,04 & 44,71 \\
\hline
\end{tabular}

Composite soil samples were taken by using a core sampler in different soil depths (Soil quality. ДСТУ 4287:2004). The fractioning of macro- dry aggregates by use of different sieves was fulfilled by ДСТУ 4744:2007, water stable aggregates determination was fulfilled by use of Baksheev device. A high vacuum slow wetting approach prior to determining soil aggregate stability was fulfilled to determine MWD, GMD, D in Chinese soil samples. Fifty grams of air-dried soil sample was fixed on the tray in the desiccator, submerged for 2-4 min with distilled water at $1.8 \mathrm{Hg}$ pressure. Followed by transferring to the top sieve of the nest and submerged in distilled water for 8 min for aggregate stability analysis, samples was then set in oscillating motion $3-\mathrm{cm}$ up and down, with a rate of 30 cycles per minute for 2 min. Then, the stable soil aggregates that stayed above the sieve were weighed after ovendrying to calculate WSA. The result was summarized by the mean weight diameter (MWD; mm), the geometric mean diameter (GMD; $\mathrm{mm}$ ), the fractal dimension (D): 


$$
\begin{aligned}
& \mathrm{MWD}=\sum_{i=1}^{n} \bar{X}_{i} W_{i}, \\
& \mathrm{GMD}=\exp \left[\sum_{i=1}^{n} W_{i} \log _{e} \bar{X}_{i}\right], \\
& \lg \left[\frac{W<\bar{x}_{i}}{W_{0}}\right]=(3-\mathrm{D}) \lg \left(\frac{\bar{X}_{i}}{x_{\max }}\right),
\end{aligned}
$$

where $\bar{X}_{i}$ is the mean diameter of aggregate fraction $i$;

$W_{i}$ is the mass proportion of aggregate fraction $i$, with $n=6$ including the class of material $<0.25 \mathrm{~mm}$;

$W$ is the cumulative mass of particles smaller than $\bar{X}_{\bar{i}}$;

$W_{0}$ is the total mass of any sizes of soil particles; $X_{\max }$ is the maximum fraction diameter of aggregates.

For other analyses, the soil properties were estimated using national standards (ДСТУ) approaches.

Results and Discussion. Tillage practices impacted the soil aggregates distribution in different layers of Ukrainian Mollisol. Soil aggregates larger than $10 \mathrm{~mm}$ in upper horizon were crashed by field machinery in the spring-summer period. By this reason the content of macroaggregates in $0-5 \mathrm{~cm}$ soil layer was minimal but increased downwards the soil profile (Table 2). At the same time the amount of the smallest $<0,25 \mathrm{~mm}$ fraction taken from that soil horizon was the greatest. Variants from minimum tillage and deep minimum tillage formed the most valuable $10-0,25 \mathrm{~mm}$ meso-aggregates on a large quantity versus to plowing: $77.04 \%, 79.71 \%$ versus $74.83 \%$ in $0-5 \mathrm{~cm}$ layer; $72.94 \%, 76.81 \%$ versus $70.73 \%$ in $5-10 \mathrm{~cm}$ layer, $73,82 \%, 62.69 \%$ versus $66.38 \%$ in $10-20$ $\mathrm{cm}$ layer and $75.64 \%, 71.1 \%$ versus $64.81 \%$ in $20-40 \mathrm{~cm}$ soil layer. The amount of deflation proof aggregates larger than $1 \mathrm{~mm}$ from $0-10 \mathrm{~cm}$ soil layer was the greatest under deep minimum tillage - $76.57 \%$. Our findings demonstrate that the use of tillage practices strongly influences the soil aggregates distribution in different layers of Mollisols. Agronomical valuable $10-0,25 \mathrm{~mm}$ aggregates were formed much better under minimum tillage. The difference in soil aggregates distribution among tillage treatments did not significantly affect the level of structural coefficient.

The water stable aggregates in Ukrainian and Chinese Mollisols (Figure 1) are mainly distributed in the peds sized $1-0.25 \mathrm{~mm}$. Plowing practices favored water stable aggregate generation in peds $<0.25 \mathrm{~mm}$. Water stable aggregates composition of Mollisols $(0-10 \mathrm{~cm}$ soil layer) is characterized as "good" (54.84-66.78 \%) for $>0.25 \mathrm{~mm}$ fractions, even with different tillage effect, but a higher amount one was under RT in Ukrainian and NT in Chinese Mollisols. The greatest quantity of water stable aggregates stocks was accumulated at fractions: $0.5-10 \mathrm{~mm}$ under NT, $<0.5 \mathrm{~cm}-$ under CT in Chinese Mollisol; $1-5 \mathrm{~mm}$ and $<0.5 \mathrm{~mm}$ - under CT, 0.5-1.0 mm - under RT in Ukrainian Mollisol. The substantival composition of $<0.25 \mathrm{~mm}$ fraction was $1,21,1,66$ - under CT, NT in Chinese and в 1,64; 1,87; 2,01 - under CT, DT i RT in Ukrainian Mollisols. The content of 5-10, 2-5, 1-2 mm fractions hadn't significant differences between all tillage. 
2. Soil aggregates distribution under different systems of soil tillage in Ukrainian and Chinese Mollisols

\begin{tabular}{|c|c|c|c|c|c|c|c|c|c|}
\hline \multirow{2}{*}{$\begin{array}{l}\text { Soil } \\
\text { layer, } \\
\mathrm{cm}\end{array}$} & \multicolumn{9}{|c|}{ Dry aggregates fractions, $\%$} \\
\hline & $>10$ & $10-7$ & $7-5$ & $5-3$ & $3-2$ & $2-1$ & $1-0,5$ & $0,5-0,25$ & $<0,25$ \\
\hline \multicolumn{10}{|c|}{ Ukrainian Mollisol } \\
\hline \multicolumn{10}{|c|}{$\mathrm{RT}$} \\
\hline $0-5$ & 10,57 & 6,57 & 6,10 & 19,80 & 9,70 & 12,80 & 12,88 & 9,20 & 12,39 \\
\hline $5-10$ & 19,20 & 5,36 & 7,23 & 14,97 & 9,21 & 12,82 & 13,93 & 9,43 & 7,86 \\
\hline $10-20$ & 21,98 & 11,75 & 14,86 & 20,93 & 8,73 & 8,15 & 7,58 & 1,83 & 4,21 \\
\hline $20-30$ & 19,92 & 12,88 & 14,95 & 21,20 & 8,45 & 8,64 & 6,42 & 4,35 & 3,18 \\
\hline $30-40$ & 16,93 & 9,57 & 10,10 & 18,50 & 9,12 & 10,70 & 9,93 & 6,48 & 8,68 \\
\hline \multicolumn{10}{|c|}{ CT } \\
\hline $0-5$ & 6,85 & 5,69 & 7,64 & 16,34 & 9,32 & 11,65 & 13,38 & 10,81 & 18,31 \\
\hline $5-10$ & 22,32 & 12,25 & 11,07 & 17,69 & 7,90 & 8,90 & 8,03 & 4,89 & 6,95 \\
\hline $10-20$ & 29,45 & 10,28 & 9,97 & 14,82 & 7,42 & 8,14 & 7,42 & 4,63 & 7,86 \\
\hline $20-30$ & 19,23 & 7,60 & 7,93 & 16,03 & 8,85 & 10,47 & 10,26 & 6,94 & 12,69 \\
\hline $30-40$ & 30,00 & 10,32 & 8,94 & 14,68 & 7,23 & 7,34 & 6,81 & 6,24 & 8,45 \\
\hline \multicolumn{10}{|c|}{ DT } \\
\hline $0-5$ & 8,20 & 5,40 & 8,07 & 16,58 & 9,69 & 14,19 & 16,34 & 9,44 & 12,09 \\
\hline $5-10$ & 21,27 & 16,82 & 13,70 & 27,99 & 6,33 & 4,91 & 4,54 & 2,53 & 1,92 \\
\hline $10-20$ & 29,85 & 8,71 & 9,84 & 17,49 & 8,44 & 9,75 & 8,52 & 3,65 & 3,77 \\
\hline $20-30$ & 22,73 & 10,28 & 13,90 & 16,85 & 10,72 & 10,43 & 7,33 & 3,58 & 4,19 \\
\hline $30-40$ & 21,11 & 10,31 & 10,33 & 16,80 & 8,74 & 9,22 & 8,29 & 5,43 & 9,77 \\
\hline \multicolumn{10}{|c|}{$\begin{array}{c}\text { Chinese Mollisol } \\
\text { CT }\end{array}$} \\
\hline $0-5$ & 20,3 & 31,3 & 26,1 & 5,8 & 6,7 & 4,6 & 5,2 & 74,5 & 2,9 \\
\hline $5-10$ & 33,3 & 26,5 & 23,1 & 4,0 & 3,6 & 2,8 & 6,7 & 60,0 & 1,5 \\
\hline $10-20$ & 41,9 & 20,8 & 21,0 & 3,1 & 3,4 & 3,0 & 6,8 & 51,3 & 1,1 \\
\hline \multicolumn{10}{|c|}{ DT } \\
\hline $0-5$ & 13,5 & 29,7 & 30,5 & 7,9 & 8,2 & 5,8 & 4,4 & 82,1 & 4,6 \\
\hline $5-10$ & 28,8 & 29,8 & 26,0 & 5,8 & 4,7 & 2,2 & 2,7 & 68,5 & 2,2 \\
\hline $10-20$ & 32,3 & 27,0 & 25,8 & 5,8 & 4,1 & 2,8 & 2,2 & 65,5 & 1,9 \\
\hline \multicolumn{10}{|c|}{ NT } \\
\hline $0-5$ & 10,9 & 27,4 & 35,4 & 11,5 & 7,9 & 3,5 & 3,5 & 85,7 & 5,9 \\
\hline $5-10$ & 26,8 & 24,9 & 28,6 & 8,8 & 5,3 & 3,3 & 2,3 & 70,9 & 2,4 \\
\hline $10-20$ & 29,2 & 24,8 & 27,1 & 8,1 & 5,9 & 3,0 & 1,8 & 68,9 & 2,2 \\
\hline \multicolumn{10}{|c|}{$\mathrm{HIP}_{05}$} \\
\hline $0-20$ & 4,1 & 2,9 & 2,8 & 1,7 & 1,1 & 1,4 & 2,3 & 4,7 & 0,4 \\
\hline
\end{tabular}




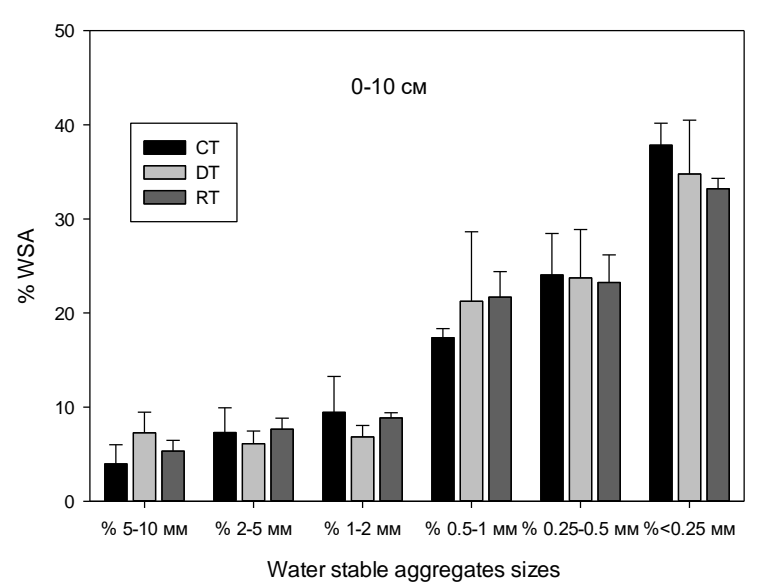

a)

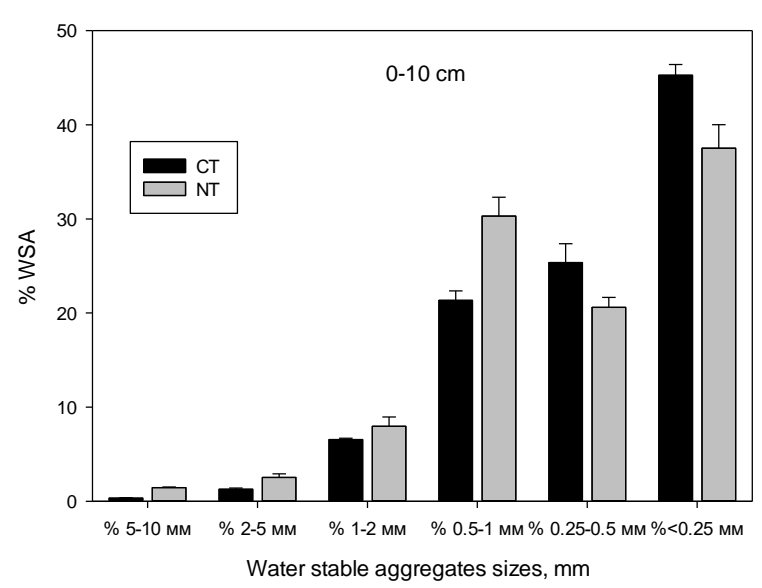

b)

Fig. 1. Tillage effect on WSA fractions from $0-10 \mathrm{~cm}$ layer of: (a) Ukrainian, (b) Chinese Mollisols (Kravchenko et al., 2015)

A high vacuum slow wetting approach demonstrated the predominant accumulation of the water stable aggregates in $>1 \mathrm{~mm}$ and $1-0.25 \mathrm{~mm}$ fractions in Chinese Mollisol (Fig. 2). No-till practices were favored in generation of water stable aggregates $>1 \mathrm{~mm}$, rotatory tillage and moldboard plow - 1-0.25 mm aggregates, moldboard plow and combined tillage $-<0.25 \mathrm{~mm}$ aggregates.

Another important factor of the land surface resistance to erosion may be determined by MWD, GMD and (3-y/x (Df). Every index has a different evaluation purpose. MWD displays the percentage of large aggregates retained in the sieves increases, GMD estimates the sizes of the most frequent aggregate size classes, $3-y / x(D f)$ are suited to characterize soil structural stability. Smaller fractal dimensions are associated with more stable soil aggregates. Conventional soil tillage accelerated soil aggregates destruction and decreased of aggregate stability (Table 3).
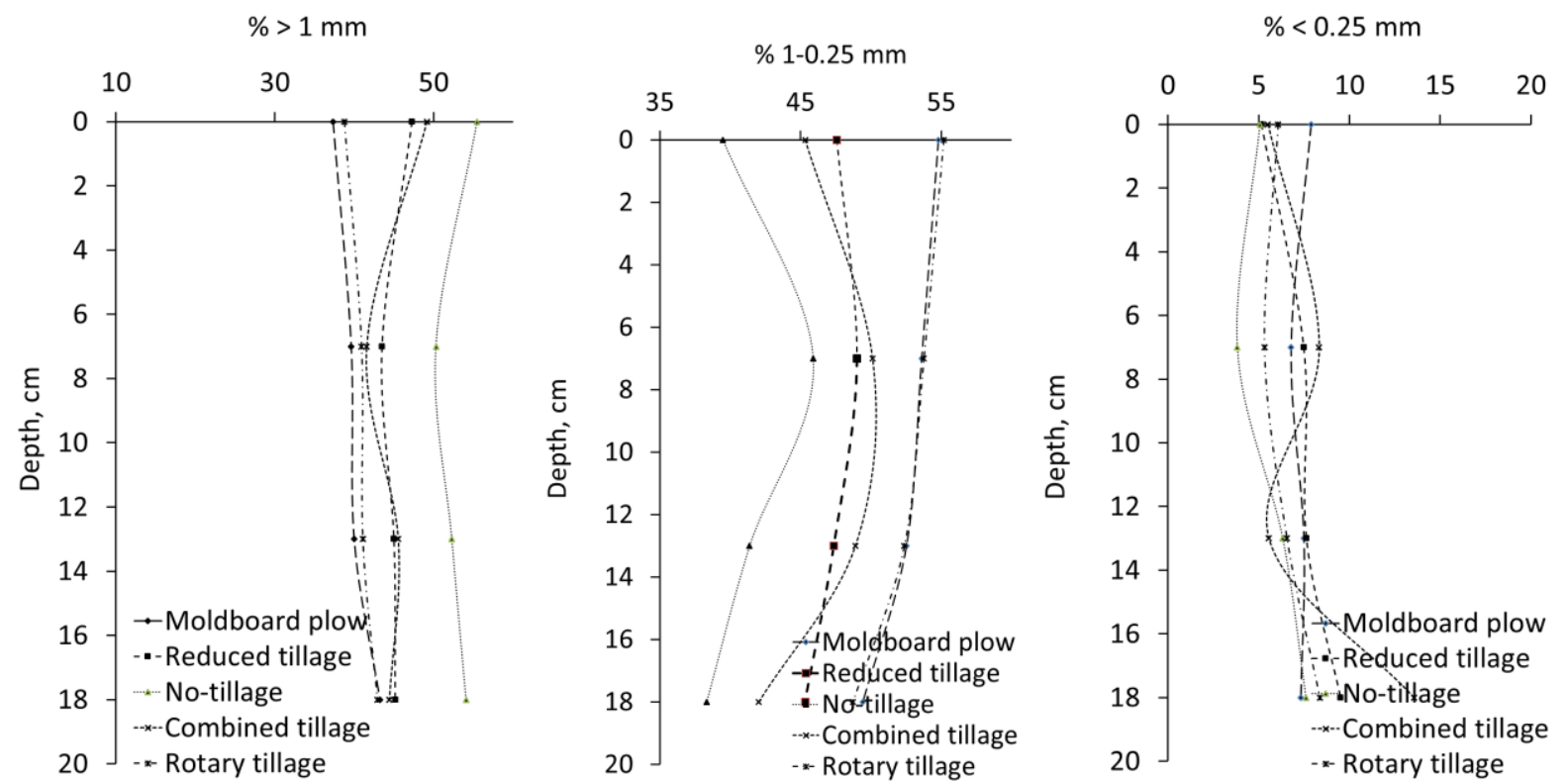

Fig. 2. The distribution of water-stable aggregates in Chinese mollisols under different soil tillage systems 
3. Mean weight diameter (MWD), geometric mean weight diameter (GMD) and fractal dimensions $((3-y / x(D f))$ of $0-10 \mathrm{~cm}$ layer Chinese Mollisol under different tillage

\begin{tabular}{l|c|c|c|}
\hline Land use & GMD & MWD & $3-y / x(D f)$ \\
\hline NT & 1.64 & 2.51 & 2.36 \\
RT & 1.71 & 2.59 & 2.28 \\
CT & 1.41 & 2.07 & 2.53 \\
Ab & 2.00 & 2.97 & 2.09 \\
\hline
\end{tabular}

NT and RT had higher values of GMD (1.64, $1.71 \mathrm{~mm})$ and MWD (2.51, $2.59 \mathrm{~mm}$ ) compared to CT $(1.41,2.07 \mathrm{~mm})$. The highest mean values of MWD, GMD and lowest of 3-y/x (Df) were in abandoned land (Ab): $2.00 \mathrm{~mm}, 2.97 \mathrm{~mm}$, 2.09 correspondingly.

Conclusions. Tillage practices strongly influence the soil aggregates distribution in Ukrainian and Chinese Mollisols. Agronomical valuable 10-0.25 mm air-dry aggregates were formed much better under no-till and minimum tillage. Water stable aggregates composition of all Mollisols is characterized as "good" for $>0.25 \mathrm{~mm}$ fractions. A high vacuum slow wetting approach provided the more reliable and accurate description of WSA, had the lowest coefficient of variation and variance. The smallest 3-y/x (Df) and highest MWD and GMD indexes were defined under Ab, NT and RT NT and CT in $\mathbf{0 - 1 0} \mathrm{cm}$ layer of Chinese Mollisol.

\section{References.}

1. Andruschkewitsch, R., Koch, Heinz-Josef, Ludwig, B. (2014). Effect of longterm tillage treatments on the temporal dynamics of water-stable aggregates and on macro-aggregate turnover at three German sites. Geoderma, (217-218), 57-64.

2. Blanco-Canqui, H. and Lal, R. (2007). Soil structure and organic carbon relationships following 10 years of wheat straw management in no-till. Soil and Tillage Research, 95, 240-254.

3. Denef, K., Six, J., Merckx, R., Paustian, K. (2004). Carbon sequestration in microaggregates of no-tillage soils with different clay mineralogy. Soil Science Society of America, 68, 1935-1944.

4. Hou, X., Li, R., Jia, Z., Han, Q. (2013). Effect of Rotational Tillage on Soil Aggregates, Organic Carbon and Nitrogen in the Loess Plateau Area of China. Pedosphere, 23(4), 542-548.

5. Irfan, A., Tariq M., Rafiq, I. (2013). Effect of long term no-till and conventional tillage practices on soil quality. Soil \& Tillage Research, 131, 28-35.

6. Kong, A.Y.Y., Six, J., Bryant, D.C., Denison, R.F., van Kessel, C. (2005). The relationship between carbon input, aggregation, and soil organic carbon stabilization in sustainable cropping systems. Soil Science Society of America, 69, 1078-1085.

7. Kravchenko, Y., Beregnyak, E., Matviiv, G., Zhang, X., Chen, Y., Song, C. (2015). Agrophysical properties of Ukrainian Chernozem and Chinese Isohumusol under different tillage. Herald of Agrarian Science, 9 (751),17-23.

8. Six, J. (2000). Soil structure and organic matter: Distribution of aggregate-size classes and aggregate-associated carbon. Soil Science Society of America, 64, 681-689.

9. Zhao, J., Chen, S., Hu, R., Li, Y. (2017). Aggregate stability and size distribution of red soils under different land uses integrally regulated by soil organic matter, and iron and aluminum oxides. Soil \& Tillage Research, 167: 73-79. 


\title{
СТІЙКІСТЬ ТА ФРАКЦІЙНИЙ ПЕРЕРОЗПОДІЛ ҐРУНТОВИХ АГРЕГАТІВ УКРАЇНСЬКИХ ТА КИТАЙСЬКИХ МОЛЛІСОЛІВ ЗА РІЗНОГО ОБРОБІТКУ ҐРУНТУ
}

\author{
Ю. С. Кравченко
}

Анотація. Дослідження були виконані з наміром визначення впливу землекористування на перерозподіл грунтових агрегатів в українських $i$ китайських моллісолях. Значна увага приділялась вивченню грунтозахисного обробітку. Дані наукові дослідження були виконані при експериментальних наукових станціях, розташованих в Лісостепу України (с. Великоснітинське, Київська область) та у китайській провінції Хейлунцзян (м. Хайлунь, Північно-Східний Китай). Одержані результати вказали на переваги no-till та мінімального обробітку грунту щодо збільшення вмісту агрономічно-цінних 10-0,25 см повітряно-сухих агрегатів ірунту, сприяння у генеруванні водотривких агрегатів (більше 0,5 мм), формуванні агрегатів із більшим середньозваженим (MWD) та геометричним середнім діаметром (GMD) та нижчими фррактальними характеристиками (3-y/x (Df)).

Ключові слова: чорноземи, агрегати, ґрунтозахисний обробіток, геометричний діаметр

\section{СТОЙКОСТЬ И ФРАКЦИОННОЕ ПЕРЕРАСПРЕДЕЛЕНИЕ ПОЧВЕННЫХ АГРЕГАТОВ УКРАИНСКИХ И КИТАЙСКИХ МОЛЛИСОЛЕЙ ПРИ РАЗНОЙ ОБРАБОТКЕ ПОЧВЫ}

\author{
Ю. С. Кравченко
}

Аннотация. Исследования были выполнены с намерением определения влияния землепользования на перераспределение почвенных агрегатов в украинском и китайских моллисолях. Значительное внимание уделялось изучению почвозащитной обработке. Данные научные исследования были выполнены при экспериментальных научных станциях, расположенных в Лесостепи Украины (с. Великоснитинське, Киевская область) и в китайской провинции Хэйлунцзян (м. Хайлунь, СевероВосточный Китай). Полученные результаты указали на преимущества no-till и минимальной обработки почвы в увеличении содержания агрономически ценных 10-0,25 см воздушно-сухих агрегатов почвы, содействии в генерировании водопрочных агрегатов (более 0,5 мм), формировании агрегатов с большим средневзвешенным (MWD) $и$ геометрическим средним диаметром (GMD), меньшими фррактальными характеристиками (3-y/x (Df)).

Ключевые слова: черноземы, агрегаты, почвозащитная обработка, геометрический диаметр 